\title{
アンケートのまとめ
}

紙パルプ技術協会

\section{Summary of Questionnaire}

\author{
J. TAPPI
}

今同の年次大会に対する御意見及び今後の年次大会 に対する御希望をお聞きするため, 参加会員の皆さん にアンケート用紙を配布し，記入を打願いしたところ， 37名の方々の御協力が得られました。いわゆる回収率 で申しますと，分科会出席希望者 230 名に対し $42 \%$ となります。紙面の都合で記入内容を全部は御紹介で きませんが，主なものを適宜アレンジしてまとめます と次のようになります。
1. アンケート提出者の区分と分科会に対する 評価

2 つ以上の分科会に出席した方は原質・環境が 2 名, 原質・抄紙仕上が 3 名，原質・抄紙仕上・環境が 1 名 の棓 6 名で, これらの方々の評価点は各分科会に対し, $1 / 2=0.5,1 / 3=0.3$ として, 表 1 に（）队に示しま した。

表 1 アンケート提出者の区分と分科会に対する評俩

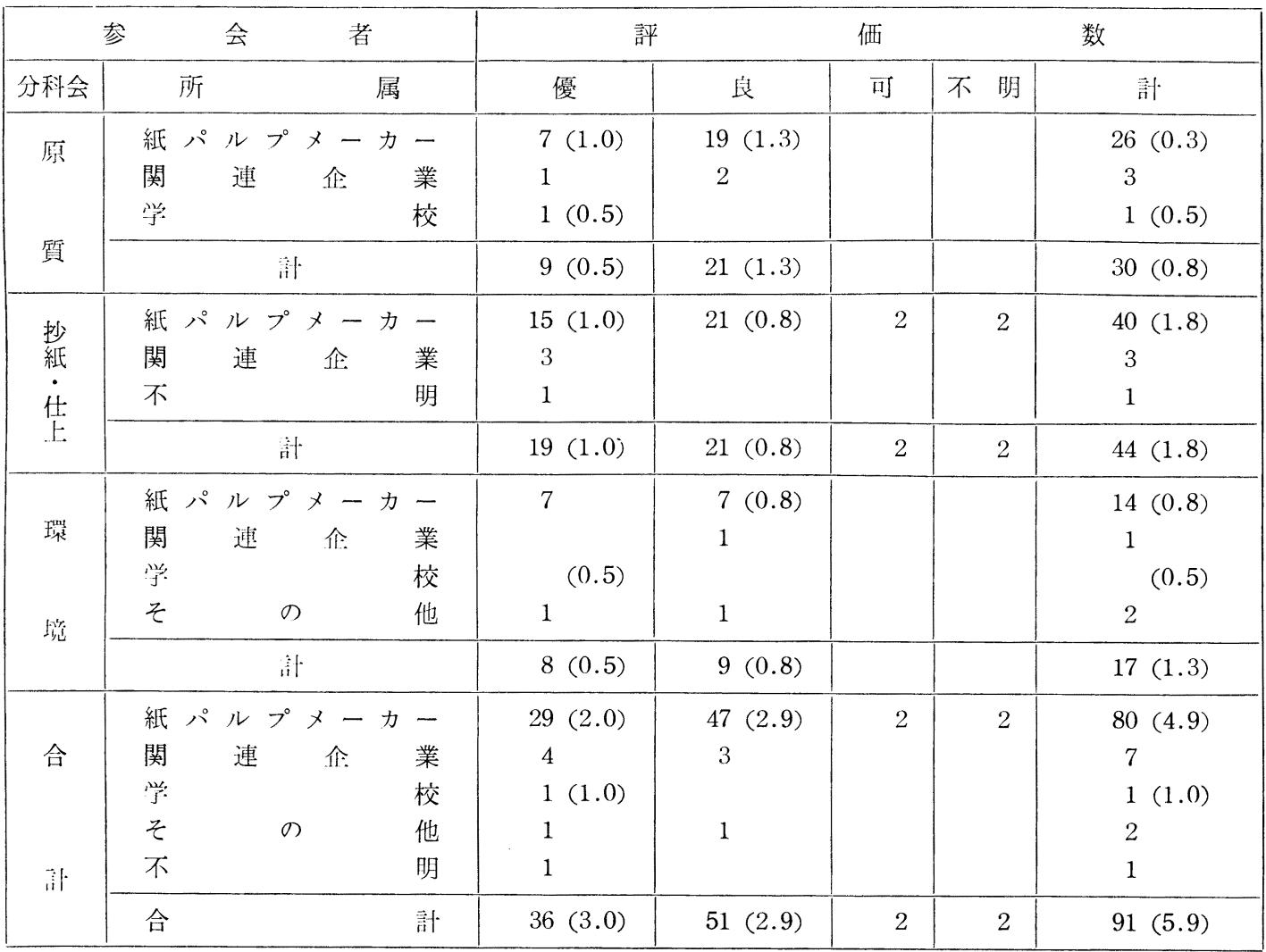




\section{2. 今回の年次大会に対する御意見}

表 2 に主な御意見をまとめて記載しました. 1 人で 5 つの事項について御意見を述べていれば 5 件に数え てあります。今年度に対する御意見か，今後に対する 御希望があいまいなものは，事務局で適当に判断して 区分しました。なお，少しでも不渾な点が司えるもの については，す心゙て“改善を希望する”の方に含めて あります。

\section{3. 今後の年次大会に対する御希望}

表 3 に主な御希望をまとめてみました。前述 2 項の 今年度の年次大会に対する改善御捻見は，ひるがえせ ば今後の年次大会に対する御希望ともなるので 2 項の 内容も羦せて, 御参照下さい。

一部の御意見にもあったように，2 日間の日程がか なりきつかった中で，多数の方々から貴重な御意見， 御希望を提出して頂き，感謝に垻えません。緍上に御

表2 今年度の年次大会に対する御意見

\begin{tabular}{|c|c|c|c|}
\hline 良かったとする意見 & 件 & 改善を希望する意見 & 件: \\
\hline \multicolumn{4}{|l|}{ 1. 全般的に見て } \\
\hline $\begin{array}{l}\text { (1) 優。非常に結構。最初の企画としてき } \\
\text { わめて良好。など } \\
\text { (2) 企画運営良かった。内容密度が高かっ } \\
\text { た。有益な講演だった。 } \\
\text { (3) 分科会形式が良かった。分科会は年次 } \\
\text { 大会にふさわしい。など } \\
\text { (4) 名称変更きわめて結構。年次大会にふ } \\
\text { さわしい大会だった。 }\end{array}$ & 22 & $\begin{array}{l}\text { (1) スケジュールが少しきつい。日程が智 } \\
\text { かすぎる。 } \\
\text { (2) 大会の運営等もっと若い人が担当した } \\
\text { らどうか。 } \\
\text { (3) 分科会の運営にもう一工夫ほしかっ } \\
\text { た。 } \\
\text { (4) あいさつ, 紹介等の時間が長すぎた。 }\end{array}$ & 2 \\
\hline \multicolumn{4}{|l|}{ 2. 分科会全体について } \\
\hline $\begin{array}{l}\text { (1) オフレコとしたのは良かった。同一ホ } \\
\text { テル内の } 3 \text { 分科会は良い。 }\end{array}$ & 2 & $\begin{array}{l}\text { (1) } 2 \text { 分科会以上聞けるようにしてほしか } \\
\text { った。 }\end{array}$ & 2 \\
\hline \multicolumn{4}{|l|}{ 3. 原質分科会 } \\
\hline $\begin{array}{l}\text { (1) 活発で非常に良かった。現場的な内容 } \\
\text { で良かった。司会, 請師ともに良かっ } \\
\text { た。など }\end{array}$ & 15 & $\begin{array}{l}\text { (1) プリントを読むだけの人が多い。質疑 } \\
\text { の時間がほしい。照明暗くメモがとれ } \\
\text { ない。など }\end{array}$ & 9 \\
\hline \multicolumn{4}{|l|}{ 4. 抄紙. 仕上分科会 } \\
\hline $\begin{array}{l}\text { (1) 貴重な現場体験 で参考になる所が多 } \\
\text { い。積極的な質疑応答が非常に良かっ } \\
\text { た。ベルベイ, コンピュータ有意義だ } \\
\text { った。など }\end{array}$ & 12 & $\begin{array}{l}\text { (1) 内容が大ざっぱすぎる。プレス脱水, } \\
\text { 地合形成などに分けたらよい。時間が } \\
\text { 短く総花的。参会者間の討論もさせて } \\
\text { ほしい。など }\end{array}$ & 8 \\
\hline \multicolumn{4}{|l|}{ 5. 環境分科会 } \\
\hline $\begin{array}{c}\text { （1）まとまりが良かった。排水処理対策の } \\
\text { 実操業の報告を聞いて有意義だった。 }\end{array}$ & 2 & $\begin{array}{l}\text { (1) 水質関係以外のものも聞きたかった。 } \\
\text { 設備メーカーの発言が多すぎた。など }\end{array}$ & 3 \\
\hline \multicolumn{4}{|l|}{ 6. 見学会について } \\
\hline $\begin{array}{l}\text { （1）十分堪能させて頂き感謝する。 } \\
\text { (2) } 4 \text { グループにそれぞれ多くの案内者を } \\
\text { つけて頂き，大変有難かった。 }\end{array}$ & 1 & $\begin{array}{l}\text { （1）時間が少なかった。現場の人々にもっ } \\
\text { と聞きたかった。 } \\
\text { (2) 分科会別に見学した方がよかった。 }\end{array}$ & 5 \\
\hline
\end{tabular}


表 3 今後の年次大会に対する希望

\begin{tabular}{|c|c|c|c|c|c|}
\hline \multicolumn{2}{|l|}{ 対 } & 象 & 希 & 望 & \\
\hline \multicolumn{3}{|c|}{ 全般·全体会議 } & $\begin{array}{l}\text { 1. 今回の方式を暫 } \\
\text { 2. 開催地や内容を巨 } \\
\text { 3. 毎年 “目玉商品” } \\
\text { 4. 開催地の特色を护 } \\
\text { 5. 学校・公共機関 } \\
\text { も含めて) } \\
\text { 6. 講演・分科会に } \\
\text { 7. オープニング・ } \\
\text { 8. 基調講演は } 2 つ を \\
\text { もよい } \\
\text { 9. 受賞記念講演にも }\end{array}$ & $\begin{array}{l}\text { らどらか } \\
\text { ること } \\
\text { と } \\
\text { :会にしてほしい } \\
\text { っと参加するよら働きかけること（分科会発表 } \\
\text { 見学会に } 1 \text { 日 } \\
\text { 必ず行った方がよい } \\
\text { 紙パ以外の講師の話を聞きたい。政治家の話で } \\
\text { トがほしい }\end{array}$ & $\begin{array}{l}2 \\
1 \\
1 \\
1\end{array}$ \\
\hline \multicolumn{6}{|c|}{ 分 科 会 } \\
\hline \multicolumn{3}{|c|}{ (1) 全 般 } & $\begin{array}{l}\text { 1. 分科会形式賛成, } \\
\text { 2. ある大きなテー } \\
\text { なくして内容充严 } \\
\text { な }\end{array}$ & $\begin{array}{l}\text { させること } \\
\text { それに関係ある発表にした方がよい。件数を少 } \\
\end{array}$ & 3 \\
\hline (2) & 時 & 間 & $\begin{array}{l}\text { 3. 分科会に丸 } 1 \text { 日。 } \\
\text { 4. 全体会議を減らし } \\
5 . \text { 討議にもっと時汫 }\end{array}$ & $\begin{array}{l}\text { ヒらどうか。 } \\
\text { 会を長くすること } \\
\text { 夹させてほしい }\end{array}$ & $\begin{array}{l}5 \\
1 \\
1\end{array}$ \\
\hline & \multicolumn{2}{|c|}{$\begin{array}{l}\text { 他分科会へ } \\
\text { の参加 }\end{array}$} & $\begin{array}{l}\text { 6. 全部の発表を受言 } \\
\text { 7. 他の分科会にも柇 }\end{array}$ & らようにしたい & $\begin{array}{l}2 \\
2\end{array}$ \\
\hline & \multicolumn{2}{|c|}{$\begin{array}{l}\text { パネルディ } \\
\text { スカッショ }\end{array}$} & 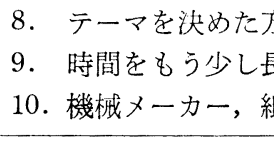 & 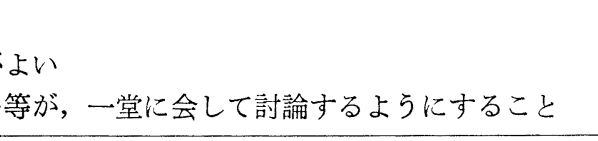 & $\begin{array}{l}2 \\
3 \\
4\end{array}$ \\
\hline (5) & 区分 $\cdot P$ & & 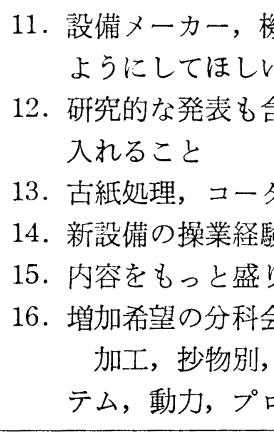 & $\begin{array}{l}\text {, 用具メーカー, 紙のユーザー等の話も入れる } \\
\text { た方がよい。将来のビジョン, 基礎的なものも } \\
\text { 気, 臭気, 廃棄物等の分科会がほしい。など } \\
\text { 開発経験等数少なく突っ込えでやってほしい } \\
\text { ほしい } \\
\text { 紙, 基礎研究, 試験研究, 製品品質, 流通シス } \\
\text { カニカル的に分離, 抄紙と仕上の分離 }\end{array}$ & $\begin{array}{l}3 \\
6 \\
1 \\
3 \\
8\end{array}$ \\
\hline 見 & 学 & 会 & $\begin{array}{l}\text { 1. 見学会 } 1 \text { 日, そo } \\
\text { 2. 分科会ごと, あ } \\
\text { どうか }\end{array}$ & 数通りに分けて，時間をかけるようにしたら & 2 \\
\hline そ & の & 他 & $\begin{array}{ll}\text { 1. 会場の大きさにま } & \text { 説明は判りにくレ } \\
\text { 2. 講演 (発表) 要旨 } \\
\text { 3. 要旨集の中に簡冒 } \\
\text { 4. 要旨集の右側を白 }\end{array}$ & $\begin{array}{l}\text { ドを使うように準備すること。スライドによる } \\
\text { 配布すること } \\
\text { グラムを入れたらよい } \\
\text { モを注記できるようにしたらどうか }\end{array}$ & $\begin{array}{l}4 \\
4 \\
1 \\
1\end{array}$ \\
\hline
\end{tabular}




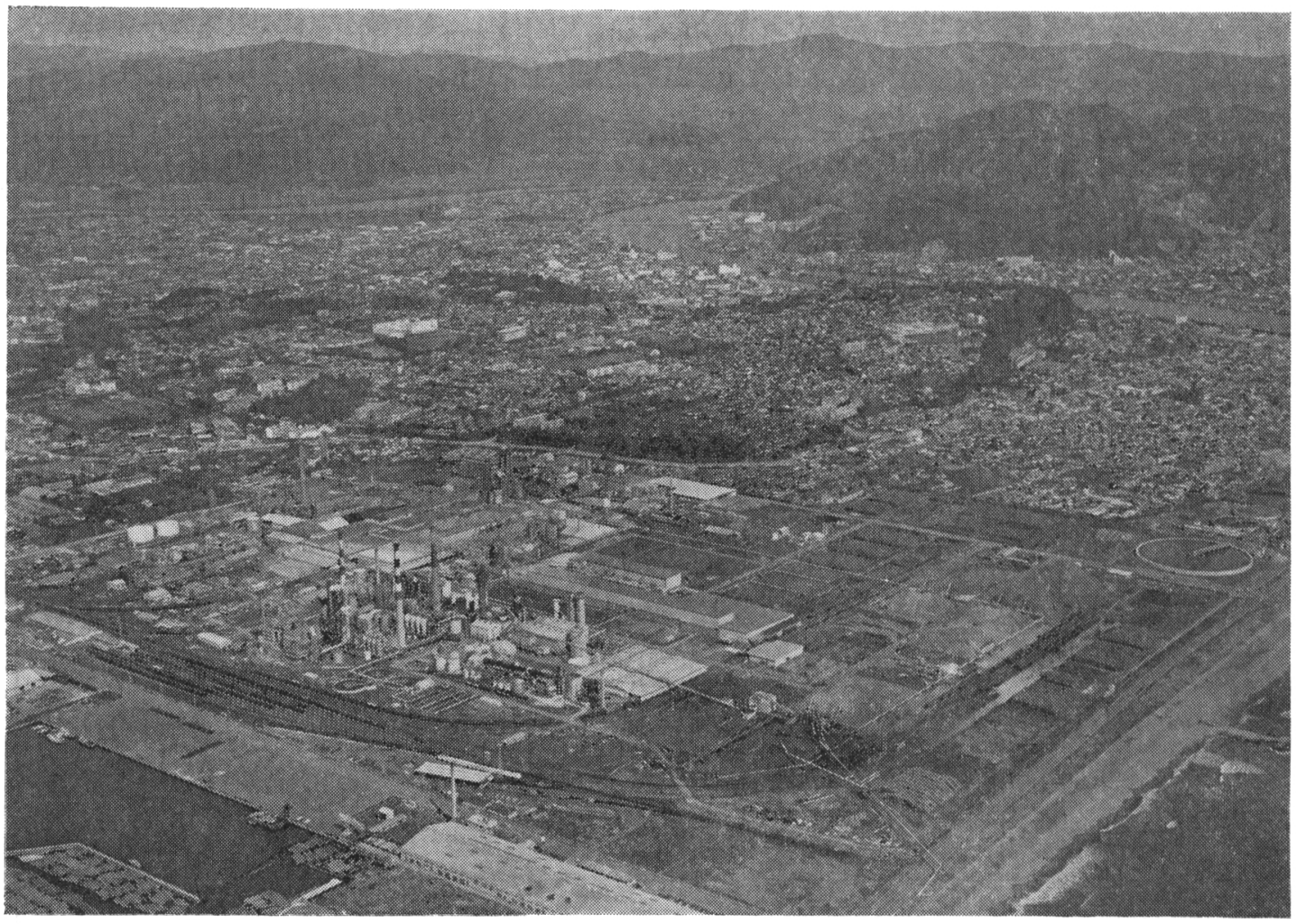

十条製紙（株）石巻工場

紹介できなかったものも含めて, 今後の年炊大会の参 考て頂き，より充実した大会を企画・運営する つもりです。53年度の年次大会に更に多くの会員の方
々が参加されることを心から念じつつ，アンケートの まとめの報告を終ります。有難らございました！

（山陽国策パルプ森 平松記） 